\title{
Regional atmospheric circulation change in the North Pacific during the Holocene inferred from lacustrine carbonate oxygen isotopes, Yukon Territory, Canada
}

\author{
Lesleigh Anderson ${ }^{\mathrm{a}, *}$, Mark B. Abbott ${ }^{\mathrm{b}, 1}$, Bruce P. Finney ${ }^{\mathrm{c}, 2}$, Stephen J. Burns ${ }^{\mathrm{a}, 3}$ \\ ${ }^{a}$ Department of Geosciences, University of Massachusetts Amherst, Amherst, MA 01003, USA \\ ${ }^{\mathrm{b}}$ Department of Geology and Planetary Science, University of Pittsburgh, Pittsburgh, PA 15260-3332, USA \\ ${ }^{\mathrm{c}}$ Institute of Marine Science, University of Alaska Fairbanks, Fairbanks, AK 99775, USA
}

Received 10 September 2004

Available online 24 May 2005

\begin{abstract}
Analyses of sediment cores from Jellybean Lake, a small, evaporation-insensitive groundwater-fed lake, provide a record of changes in North Pacific atmospheric circulation for the last $\sim 7500 \mathrm{yr}$ at 5- to 30-yr resolution. Isotope hydrology data from the southern Yukon indicate that the oxygen isotope composition of water from Jellybean Lake reflects the composition of mean-annual precipitation, $\delta^{18} \mathrm{O}_{\mathrm{p}}$. Recent changes in the $\delta^{18} \mathrm{O}$ of Jellybean sedimentary calcite $\left(\delta^{18} \mathrm{O}_{\mathrm{ca}}\right)$ correspond to changes in the North Pacific Index (NPI), a measure of the intensity and position of the Aleutian Low (AL) pressure system. This suggests that $\delta^{18} \mathrm{O}_{\mathrm{p}}$ variability was related to the degree of fractionation during moisture transport from the Gulf of Alaska across the St. Elias Mountains and that Holocene shifts were controlled by the intensity and position of the AL. Following this model, between $\sim 7500$ and 4500 cal yr B.P., long-term trends suggest a predominantly weaker and/or westward AL. Between $\sim 4500$ and 3000 cal yr B.P. the AL shifted eastward or intensified before shifting westward or weakening between $\sim 3000$ and 2000 cal yr B.P. Rapid shifts eastward and/or intensification occurred $\sim 1200$ and 300 cal yr B.P. Holocene changes in North Pacific atmospheric circulation inferred from Jellybean Lake oxygen isotopes correspond with late Holocene glacial advances in the St. Elias Mountains, changes in North Pacific salmon abundance, and shifts in atmospheric circulation over the Beaufort Sea. (C) 2005 University of Washington. All rights reserved.
\end{abstract}

Keywords: Jellybean Lake; Holocene; Isotope

\section{Introduction}

The intensity and position of the Aleutian Low (AL), the semi-permanent low pressure located over the Gulf of Alaska, has emerged as an important control on Northwest Pacific Holocene climate (e.g., Edwards et al., 2001; Heusser et al., 1985; Latif and Barnett, 1994; Mann et al.,

\footnotetext{
* Corresponding author. Fax: +14135451200 .

E-mail addresses: land@geo.umass.edu (L. Anderson), mabbott1@pitt.edu (M.B. Abbott), finney@ims.uaf.edu (B.P. Finney), sburns@geo.umass.edu (S.J. Burns).

${ }^{1}$ Fax: +1 4126243914

${ }^{2}$ Fax: +19074747204 .

${ }^{3}$ Fax: +14135451200 .
}

1998). Decadal scale variability of the AL have been recognized from analyses of instrumental data and is described by climate indices such as the North Pacific index (NPI) (Trenbirth and Hurrell, 1994) and the Pacific Decadal Oscillation (PDO) (Mantua et al., 1997). These indices are correlated with tree-ring and salmon abundance data (e.g., Biondi et al., 2001; Mantua et al., 1997) and snow accumulation, a proxy for moisture delivery (Bitz and Battisti, 1999; Moore et al., 2002a,b; Rupper et al., 2004). The AL is the main synoptic climate feature related to moisture delivery to the St. Elias Mountains of Alaska and the interior of the southern Yukon (Mock et al., 1998; Wahl et al., 1987). The St. Elias Mountains have a dramatic effect on the oxygen-isotope values of precipitation on both the coastal and interior sides of the mountains. Relatively ${ }^{18} \mathrm{O}$ - 
enriched precipitation falls on the coastal side compared to strongly ${ }^{18} \mathrm{O}$-depleted precipitation just $200 \mathrm{~km}$ inland. This large fractionation between coastal and interior precipitation suggests that changes in air mass trajectories and moisture transport history from the Gulf of Alaska either over or around the St. Elias Mountains are a principle influence on precipitation- $-{ }^{18} \mathrm{O}$ at Jellybean Lake, located $\sim 250 \mathrm{~km}$ inland in the southwest interior Yukon (Fig. 1).

Few studies have documented long-term high-resolution climatic variability beyond the last millennia from high latitudes in northwestern North America (e.g., Anderson et al., 2001; Heusser et al., 1985; Hu et al., 2001; Pienitz et al., 2000). Although recent climatic and environmental changes around the Gulf of Alaska have been documented by treering and ice core studies (D'Arrigo et al., 1999; Davi et al., 2003; Holdsworth et al., 1992; Mann et al., 1998; Wake et al., 2002; Wiles et al., 1998, 1999), these records generally extend from $<100$ to a maximum of $\sim 1000$ cal yr B.P. Comparatively little is known about high-resolution climatic variability during the Holocene in the nearby interior regions of the Yukon Territory (Pienitz et al., 2000). Holocene climate changes at century to millennial time scales in the interior Yukon Territory were inferred by geomorphological evidence of late Holocene glacial advances (Calkin et al., 2001; Denton and Karlen, 1977), pollen records (Cwynar, 1988; Cwynar and Spear, 1995; Heusser et al., 1985; Keenan and Cwynar, 1992; Lacourse and Gajewski, 2000; Spear and Cwynar, 1997; Wang and Geurts, 1991), and multi-proxy paleolimnological investigations (Pienitz et al., 2000).

There is considerable spatial climatological variability in the southern Yukon Territory and adjacent Alaska due to complex topography and the influence of air masses originating in the Arctic, Gulf of Alaska, and Bering Sea (Streten, 1974; Wahl et al., 1987). Such regional climatic heterogeneity and absence of long-term high-resolution paleoclimatic data make it difficult to adequately describe sub-century scale regional paleoclimate and investigate forcing mechanisms that caused Holocene climatic change. Recent studies have explored the possibility of cyclic

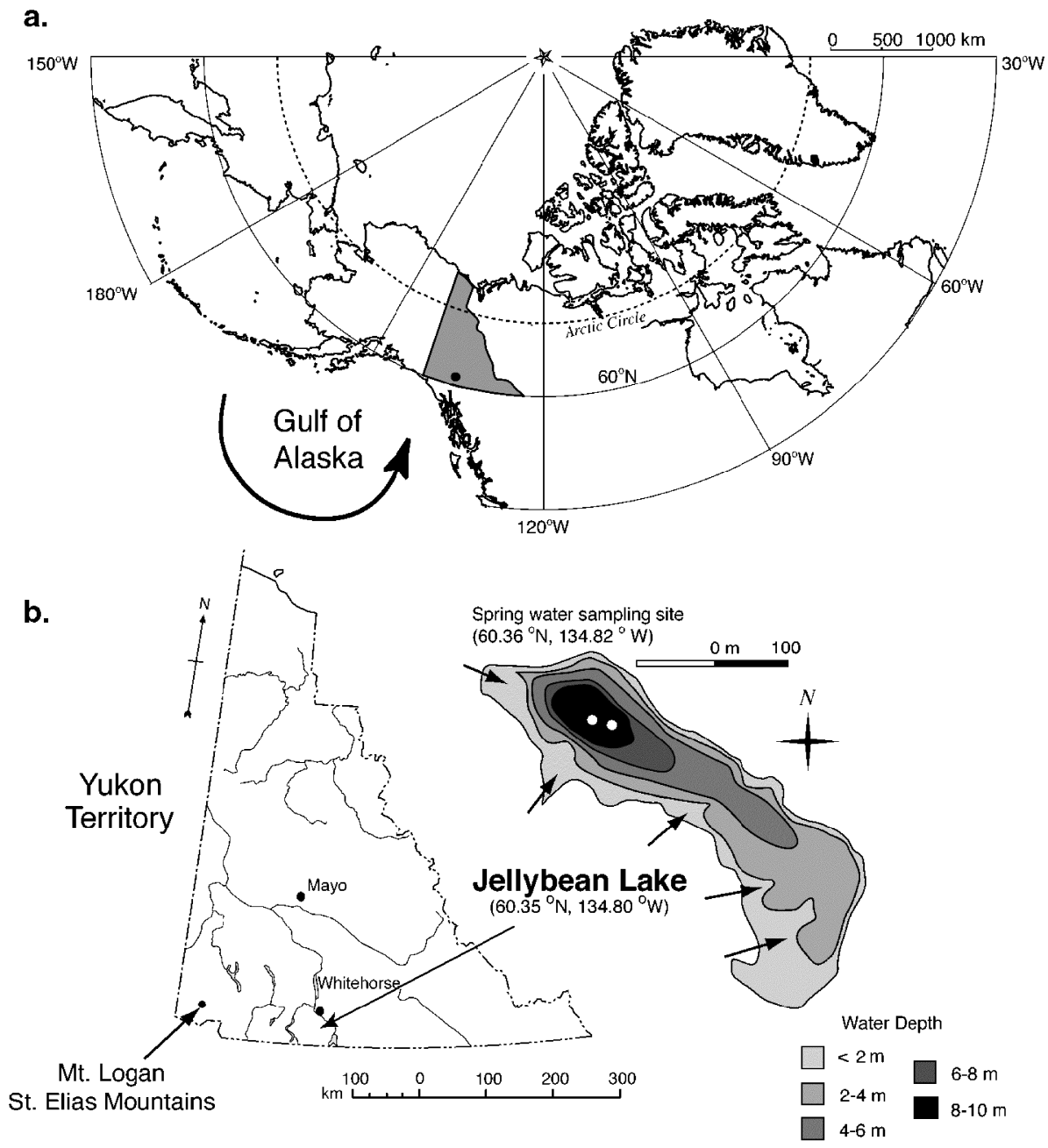

Figure 1. (a) Location map showing the Yukon Territory and sites referred to in the text. The general atmospheric circulation around the Aleutian Low in the Gulf of Alaska is indicated by the arrow, (b) bathymetry of Jellybean Lake where arrows indicate the locations of artesian springs and open circles the coring sites. 
variations in solar output (Hu et al., 2003; Wiles et al., 2004) and North Pacific ocean-atmosphere circulation changes (Heusser et al., 1985; Moore et al., 2002a,b; Spooner et al., 2003).

We analyzed oxygen isotopes in sediment cores from Jellybean Lake (Fig. 1), located in the southern Yukon interior, to improve the detail and resolution of the regional climatic history and investigate mechanisms for Holocene climatic change. Jellybean Lake is a small, hydrologically open lake located in the rain shadow of the St. Elias Mountains. Precipitation of calcium carbonate occurs within the water column, thereby allowing us to measure sedimentary carbonate oxygen isotope ratios to produce a record of paleoenvironmental change. The sampling resolution, sensitivity of the geochemical data, and chronology are of sufficient detail at this new site to document Holocene climatic variability at $\sim 5$ - to 30 -yr resolution back to $\sim 7500$ cal yr B.P.

\section{Paleoclimatic application of Jellybean Lake oxygen isotopes}

Oxygen isotope ratios of authigenic lake sediment carbonate $\left(\delta^{18} \mathrm{O}_{\mathrm{Ca}}\right)$ are related to climate because $\delta^{18} \mathrm{O}_{\mathrm{Ca}}$ is a function of (1) lake water temperature and (2) lake water $\delta^{18} \mathrm{O}$. The latter is, in turn, controlled by lake hydrology and regional climate (e.g., Edwards et al., 1996; Talbot, 1990; von Grafenstein et al., 1996). Lake water $\delta^{18} \mathrm{O}$ in hydrologically closed lakes with a small catchment to surface area ratio may be strongly influenced by the effects of evaporation. Increased evaporation leads to lake water ${ }^{18} \mathrm{O}$-enrichment. In contrast, hydrologically open lakes that have large catchment to surface area ratio, or short residence times, are typically less affected by evaporation. In such lakes the $\delta^{18} \mathrm{O}$ is mainly controlled by the $\delta^{18} \mathrm{O}$ of inflow water. The oxygen isotope composition of inflow water is influenced by several processes within the climate system including the source of the moisture, its transport path and rainout history, as well as seasonality and the air temperature during precipitation events (Ingraham, 1998). There is a strong correlation between air temperature and the $\delta^{18} \mathrm{O}$ of precipitation in northern latitudes (Dansgaard, 1964; Rozanski et al., 1992). Derivations of past atmospheric temperature from lacustrine-sediment $\delta^{18} \mathrm{O}$ usually assume that other factors such as changes in moisture source area, transport, and air mass history are relatively insignificant (e.g., Hu and Shemesh, 2003; Shemesh et al., 2001), which will not always be the case. One way to assess these factors is through studying modern isotopic, hydrologic, and limnologic conditions of the individual lakes within a study area (e.g., Hammerlund et al., 2003; Leng and Anderson, 2003; Rosqvist et al., 2004). Comparing modern lake water $\delta^{18} \mathrm{O}$ with environmental factors such as hydrology and elevation allows more reliable climatic interpretations of paleo-lake water $\delta^{18} \mathrm{O}$ results.

\section{Field area}

Jellybean Lake (informal name, $60.35^{\circ} \mathrm{N}, 134.80^{\circ} \mathrm{W}, 730$ $\mathrm{m}$ a.s.1.) is a small $\left(0.4 \mathrm{~km}^{2}\right)$, relatively deep $(11.6 \mathrm{~m})$, elongate lake located $40 \mathrm{~km}$ south of Whitehorse in the southern Yukon Territory, Canada (Fig. 1). The lake is situated in a large esker complex characterized by numerous narrow ridges $15-$ to $50-\mathrm{m}$ high composed of well-sorted gravel and sand. The esker complex presumably formed in sub-glacial and englacial tunnels during deglaciation of the southern Yukon $\sim 11,000$ yr ago (Dyke et al., 2002). The 50 -m high esker ridges along the north, east, and west sides of the lake define the lake basin. The watershed is dominated by open stands of trembling aspen (Populus tremuloides) and white spruce (Picea glauca). Sage (artemesia) and grasses (poaceae) grow on the well-drained south facing slopes. The surrounding esker ridges define a small local watershed around the lake and there is no surface inflow or outflow. A broad north-south trending ridge, $1640 \mathrm{~m}$ a.s.l., defining the eastern side of the Robinson Valley, is located $\sim 12 \mathrm{~km}$ east of Jellybean Lake and likely provides the source area for the local groundwater.

Jellybean Lake is located $\sim 250 \mathrm{~km}$ northeast of the Gulf of Alaska (Fig. 1). Coastal climate stations report over 3000 $\mathrm{mm} / \mathrm{yr}$ of annual precipitation, but a strong rain shadow effect limits annual precipitation in the southern interior regions to $\sim 250 \mathrm{~mm} / \mathrm{yr}$ (Wahl et al., 1987). Approximately $60 \%$ of annual precipitation occurs during ice-free months between May and September, when daylight is at a maximum (Fig. 2). The Gulf of Alaska is the primary source region for airflow in the Yukon (Wahl et al., 1987). Mean annual temperatures at Whitehorse are between $-2^{\circ}$ and $0^{\circ} \mathrm{C}$. July mean temperatures are between $10^{\circ}$ and $15^{\circ} \mathrm{C}$ (Environment Canada, 2003; Fig. 2). Monthly $\delta^{18} \mathrm{O}$ measurements between 1962 and 1964 A.D. show a seasonal $\delta^{18} \mathrm{O}$ cycle ranging from $-24.6 \%$ to $-16.8 \%$ (IAEA/WMO, 2001; Fig. 2). More ${ }^{18} \mathrm{O}$-enriched precipitation occurs during the summer months. The average $\delta^{18} \mathrm{O}$ and $\delta^{2} \mathrm{H}$ from May through September between 1961 and 1965 A.D. was $-18.3 \%$ and $-142.8 \%$, respectively (Table 1). Mean annual $\delta^{18} \mathrm{O}$ and $\delta^{2} \mathrm{H}$ values were $-20.4 \%$ and $-160.1 \%$ from 1962 to 1964 A.D.

\section{Methods}

Water samples were collected from Jellybean Lake, seven nearby lakes, three local springs, and 61 other lakes throughout the southern Yukon in July 2000 and 2002 to document the local and regional isotope hydrology (Anderson, 2005). Samples were taken from near-shore areas or the middle of each lake in a 30-ml HDLP Nalgene bottle. Bottles were rinsed with lake water before sample collection and sealed to avoid air bubbles. Precipitation was collected from a sustained rain event on August 6, 2000 (Table 1). Water samples were analyzed for oxygen and hydrogen 


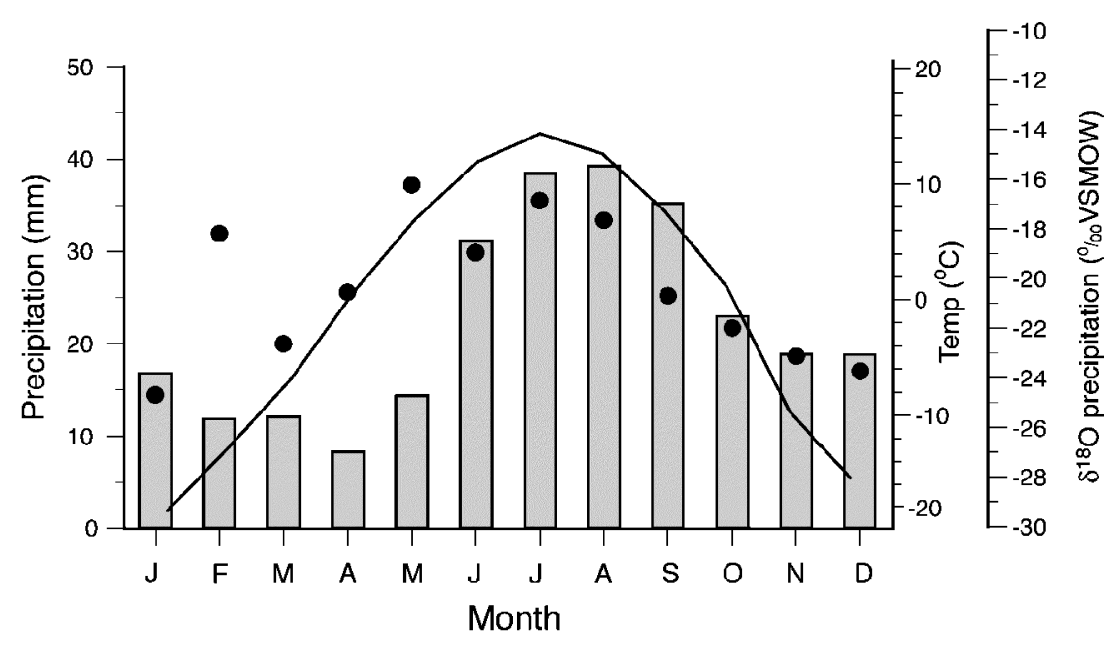

Figure 2. Monthly mean temperature (black line) and total precipitation (gray bars) at Whitehorse, Yukon Territory, between 1944 and 1990 A.D. (Environment Canada, 2003) shown with monthly averages of oxygen isotope ratios of precipitation between 1962 and 1964 A.D. (filled circle; IAEA/WMO, 2001).

isotopic composition by automated constant temperature equilibration with $\mathrm{CO}_{2}$ and automated $\mathrm{H} / \mathrm{D}$ preparation systems, respectively, for isotope ratio mass spectrometry. Results are expressed as $\delta$ values, representing deviations in per mil (\%o) from standard mean ocean water (VSMOW) such that $\delta_{\text {sample }}=\left[\left(R_{\text {sample }} / R_{\text {standard }}\right)-1\right] \times 1000 \%$, where $R$ is the ${ }^{18} \mathrm{O} /{ }^{16} \mathrm{O}$ and ${ }^{2} \mathrm{H} /{ }^{1} \mathrm{H}$ ratios in sample and standard, respectively. Analytical uncertainties are within $\pm 0.5 \%$ and $\pm 0.05 \%$ o for hydrogen and oxygen, respectively.

Water column temperature, $\mathrm{pH}$, conductivity, and dissolved oxygen were measured in July of 2000 with a Hydrolab Surveyor 4 and Datasonde 4 device. Dissolved carbon dioxide in surface lake water $\left(p \mathrm{CO}_{2}\right)$ was determined by applying Henry's Law to samples of ambient air and samples of $\mathrm{CO}_{2}$ gas collected from a head space of known volume from a container of agitated lake water (Plummer and Busenberg, 1982). Surface water samples for cation and anion chemistry were collected in $30 \mathrm{ml}$ HDLP Nalgene bottles and stored in the dark at cool temperatures. Alkalinity was determined by titration in the laboratory. Cation and anion concentrations were determined by a Dionex DX500 ion chromatograph and reported in $\mathrm{mgL}^{-1}$ (Table 2).

Lake bathymetry was determined by sonar soundings (Fig. 1). A 78-cm and 3.6-m long sediment core were retrieved from the deepest parts of Jellybean Lake from a floating platform in July 2000 and 2002 using a modified Livingstone square rod coring device that allowed preser-

Table 1

Oxygen and hydrogen isotope values for precipitation in the southern Yukon

\begin{tabular}{ll}
\hline Location and description & $\delta^{18} \mathrm{O}, \delta^{2} \mathrm{H}(\%$ VSMOW) \\
\hline Whitehorse mean annual, 1962-1964 ${ }^{\mathrm{a}}$ & $-20.4,-160.1$ \\
Whitehorse May-September, 1961-1965 & $-18.3,-142.8$ \\
Rain event, August 6, 2000 & $-22.5,-170$ \\
\hline
\end{tabular}

${ }^{\mathrm{a}}$ IAEA/WMO (2001).

${ }^{\text {b }}$ Sampled at Little Salmon Lake $\left(62.3^{\circ} \mathrm{N}, 134.9^{\circ} \mathrm{W}\right)$. vation and extrusion of the uppermost sediments in $0.5 \mathrm{~cm}$ increments. Multiple sedimentary properties were used to describe the general sedimentology of the cores. Sediments were visually logged to identify Munsell color, sedimentary structures, and biogenic features. Magnetic suscepti-

Table 2

General characteristics of surface water and surficial sediments in the southern Yukon region

\begin{tabular}{|c|c|c|c|}
\hline Parameter & $\begin{array}{l}\text { Jellybean } \\
\text { Lake }^{\mathrm{a}}\end{array}$ & $\begin{array}{l}\text { Spring } \\
\text { water }^{\mathrm{b}}\end{array}$ & $\begin{array}{l}\text { Closed } \\
\text { Lake }^{\mathrm{c}}\end{array}$ \\
\hline \multicolumn{4}{|l|}{ Water } \\
\hline $\mathrm{pH}$ & 8.2 & & 9.2 \\
\hline $\begin{array}{l}\text { Specific conductivity } \\
(\mathrm{mS})\end{array}$ & 0.30 & & 0.66 \\
\hline Temperature $\left({ }^{\circ} \mathrm{C}\right)$ & 14.8 & & 16.3 \\
\hline $\begin{array}{l}\text { Dissolved oxygen } \\
\left(\mathrm{mg} \mathrm{L}^{-1}\right)\end{array}$ & 9.5 & & 9.2 \\
\hline $\begin{array}{l}\text { Dissolved carbon dioxide } \\
(\mathrm{ppm})\end{array}$ & 868 & & 402 \\
\hline $\begin{array}{l}\text { Ambient carbon dioxide } \\
(\mathrm{ppm})\end{array}$ & 373 & & 377 \\
\hline Alkalinity $\left(\mathrm{mg} \mathrm{L}^{-1}\right)$ & 147 & 133 & 339 \\
\hline $\mathrm{Na}^{+}\left(\mathrm{mg} \mathrm{L}^{-1}\right)$ & 4.37 & 3.93 & 17.02 \\
\hline $\mathrm{K}^{+}\left(\mathrm{mg} \mathrm{L}^{-1}\right)$ & 2.24 & 1.49 & 18.64 \\
\hline $\mathrm{Mg}^{2+}\left(\mathrm{mg} \mathrm{L}^{-1}\right)$ & 7.65 & 6.85 & 70.80 \\
\hline $\mathrm{Ca}^{2+}\left(\mathrm{mg} \mathrm{L}^{-1}\right)$ & 49.94 & 50.84 & 25.38 \\
\hline $\mathrm{Cl}^{-}\left(\mathrm{mg} \mathrm{L}^{-1}\right)$ & 2.43 & 1.69 & 3.37 \\
\hline $\mathrm{NO}^{3-}\left(\mathrm{mg} \mathrm{L}^{-1}\right)$ & 2.16 & 3.4 & 1.45 \\
\hline $\mathrm{SO}_{4}^{2-}\left(\mathrm{mg} \mathrm{L}^{-1}\right)$ & 16.87 & 13.69 & 30.72 \\
\hline $\begin{array}{l}\text { Watero }{ }^{18} \mathrm{O} 2000,2002 \\
\quad \text { (average) (\%o VSMOW) }\end{array}$ & $\begin{array}{l}-21.0,-19.8 \\
(-20.4)\end{array}$ & -21.5 & $\begin{array}{l}-8.0,-7.6 \\
(-7.8)\end{array}$ \\
\hline $\begin{array}{l}\text { Water } \delta^{2} \mathrm{H} 2000,2002 \\
\quad \text { (average) (\% VSMOW) }\end{array}$ & $\begin{array}{l}-161,-157 \\
(-159)\end{array}$ & -162 & $\begin{array}{l}-106,-105 \\
(-105.5)\end{array}$ \\
\hline $\begin{array}{l}\text { Surface sediment } \delta^{18} \mathrm{O} \\
\delta^{13} \mathrm{C}(\% \mathrm{VPDB})\end{array}$ & $-19.9,5.15$ & & $-8.21,4.68$ \\
\hline $\begin{array}{l}\text { Predicted equilibrium } \\
\delta^{18} \mathrm{O} \text { of calcite }(\mathrm{VPDB})^{\mathrm{d}}\end{array}$ & -20.3 & & -8.01 \\
\hline
\end{tabular}


bility was used as a proxy for changes in mineral content and measured on half cores at a $0.5-\mathrm{cm}$ interval with a Bartington susceptibility meter (Thompson, 1986). Wet and dry bulk density and water content were determined. Weight percent organic matter and calcium carbonate were determined by the loss-on-ignition (\%LOI) method (Bengtsson and Enell, 1986; Heiri et al., 2001). Weight percent $\mathrm{CaCO}_{3}$ was estimated based on the proportion of $\mathrm{CO}_{2}$ in $\mathrm{CaCO}_{3}$ using the following calculation: [\%LOI $\left.1000^{\circ} \mathrm{C} \times(100 / 44)\right]$.

The sediment core chronology is based on ${ }^{210} \mathrm{~Pb},{ }^{137} \mathrm{Cs}$, AMS ${ }^{14} \mathrm{C}$ measurements on identifiable macrofossils, and the White River tephra (Clague et al., 1995; Table 3). Terrestrial macrofossils were not present in sufficient quantities for radiocarbon measurements at some stratigraphic levels. Therefore, purified spruce pollen samples were used (Brown et al., 1989). Both measured and calibrated ages are reported, but only calibrated ages are used for discussion. Radiocarbon ages were calibrated using CALIB 4.1 following Stuiver et al. (1998). ${ }^{210} \mathrm{~Pb}$ and ${ }^{137} \mathrm{Cs}$ activities for Jellybean Lake were measured on $0.5-\mathrm{cm}$ slices extruded in the field from a polycarbonate-barrel piston interface core. A constant rate of supply model (CRS) was used to determine ${ }^{210} \mathrm{~Pb}$ ages (Appleby, 2001; Fig. 3). A prominent ${ }^{137} \mathrm{Cs}$ peak is within $0.5 \mathrm{~cm}$ of the slice estimated to correspond to 1963 A.D. based on the ${ }^{210} \mathrm{~Pb}$ age model, leading to an estimate of \pm 5 -yr precision for the last $100 \mathrm{yr}$. An age model for Jellybean Lake was constructed using the ${ }^{210} \mathrm{~Pb}$ and ${ }^{137} \mathrm{Cs}$ data, $7{ }^{14} \mathrm{C}$ measurements, and the White River tephra (Fig. 4f). A linear interpolation between dated depths was used to determine ages of sediment samples. The chronology indicates a fairly uniform sedimentation rate, $\sim 0.05$ to $0.075 \mathrm{~mm} / \mathrm{yr}$. Based on sedimentation rates and sample thickness, the oxygen and carbon isotope samples integrate 3-6 yr in the uppermost $16.5 \mathrm{~cm}$ and $10-30 \mathrm{yr}$ for the remainder of the core.

The core was continuously sampled at high resolution for oxygen and carbon isotopes. Sub-samples of bulk sediment were taken at a $0.5-\mathrm{cm}$ increment for the uppermost 30 field- extruded samples and every $1 \mathrm{~cm}$ for the remainder of the core for a total of 351 samples. The samples were freeze dried, examined for purity, and powdered before subsampling and $\mathrm{CO}_{2}$ extraction by a Kiel automated device for isotope ratio mass spectrometry on a Finnigan Delta XL mass ratio spectrometer. Oxygen and carbon isotope results are expressed as $\delta$ values, representing deviations in per mil (\%o) from the Vienna Peedee Belemnite standard (VPDB) such that $\delta_{\text {sample }}=\left[\left(R_{\text {sample }} / R_{\text {standard }}\right)-1\right] \times 1000 \%$, where $R$ is the ${ }^{18} \mathrm{O} /{ }^{16} \mathrm{O}$ and ${ }^{13} \mathrm{C} /{ }^{12} \mathrm{C}$ ratios in sample and standard, respectively. Analytical uncertainties are within $\pm 0.1 \%$ and $\pm 0.05 \%$ or oxygen and carbon, respectively. $\delta^{18} \mathrm{O}_{\mathrm{Ca}}$ and $\delta{ }^{13} \mathrm{C}_{\mathrm{Ca}}$ values were duplicated within the range of analytical error.

\section{Results}

\section{Limnology and isotope hydrology of Jellybean Lake}

Jellybean Lake is currently thermally unstratified and chemically mixed. The water column measurements indicate only minor changes in temperature, $\mathrm{pH}$, specific conductivity, and dissolved oxygen with water depth (Anderson, 2005). Sub-surface artesian springs feed the lake at several depths, presumably maintaining the mixed state during the ice-free season. Water level appears to vary inter-annually, as the lake level in July 2002 was $1 \mathrm{~m}$ higher than July 2000. Inter-annual lake level variability is probably related to seasonal and annual changes in hydraulic pressure in the recharge area. Jellybean Lake water has a $\mathrm{pH}$ of 8.2 and is supersaturated in $\mathrm{CO}_{2}$, rich in dissolved calcium and cooler $\left(14.8^{\circ} \mathrm{C}\right)$ than a nearby thermally stratified, hydrologically closed lake of similar size $\left(16.3^{\circ} \mathrm{C}\right.$; Table 2$)$. Jellybean Lake specific conductivity and major ion concentrations are lower than the hydrologically closed lake, reflecting the effects of short residence times. The $\delta^{18} \mathrm{O}$ of Jellybean Lake water (average $-20.4 \%$ ) was identical to mean annual precipitation $(-20.4 \%$ ) and almost identical to local spring water

Table 3

Geochronological data for Jellybean Lake

\begin{tabular}{|c|c|c|c|c|c|}
\hline Core depth $(\mathrm{cm})$ & Material & Lab no. & $\begin{array}{l}\text { Measured age } \\
\left({ }^{14} \mathrm{C} \text { yr B.P. }\right)\end{array}$ & $\begin{array}{l}\text { Median-calibrated } \\
\text { age (cal yr B.P.) }\end{array}$ & $\begin{array}{l}\text { 1-Sigma range } \\
\text { (cal yr B.P.) }\end{array}$ \\
\hline 0 & & & & 2002 A.D. $^{b}$ & \\
\hline 15 & Wood & OS-38712 & $240 \pm 30$ & 1860 A.D. ${ }^{c}$ & \\
\hline 41.5 & Wood & CAMS-91761 & $920 \pm 35$ & 825 & $774-915$ \\
\hline 59.5 & Wood & CAMS-91762 & $1175 \pm 35$ & 1065 & $1013-1170$ \\
\hline 64 & White River Ash & & & $1150^{\mathrm{d}}$ & $1014-1256^{\mathrm{d}}$ \\
\hline 87 & Charcoal & CAMS-96825 & $1750 \pm 40$ & 1665 & $1574-1710$ \\
\hline 170.5 & Pollen & CAMS-92155 & $4000 \pm 35$ & 4490 & $4418-4520$ \\
\hline 244.5 & Wood & CAMS-91763 & $4800 \pm 35$ & 5500 & $5485-5591$ \\
\hline 336.5 & Pollen & CAMS-92157 & $6675 \pm 50$ & 7525 & $7505-7585$ \\
\hline
\end{tabular}

${ }^{a}$ Median intercept, CALIB 4.0 (Stuiver et al., 1998).

b Date when core was taken.

c ${ }^{210} \mathrm{~Pb}$ - and ${ }^{137} \mathrm{Cs}$-based age.

d 2-Sigma range, Clague et al. (1995). 


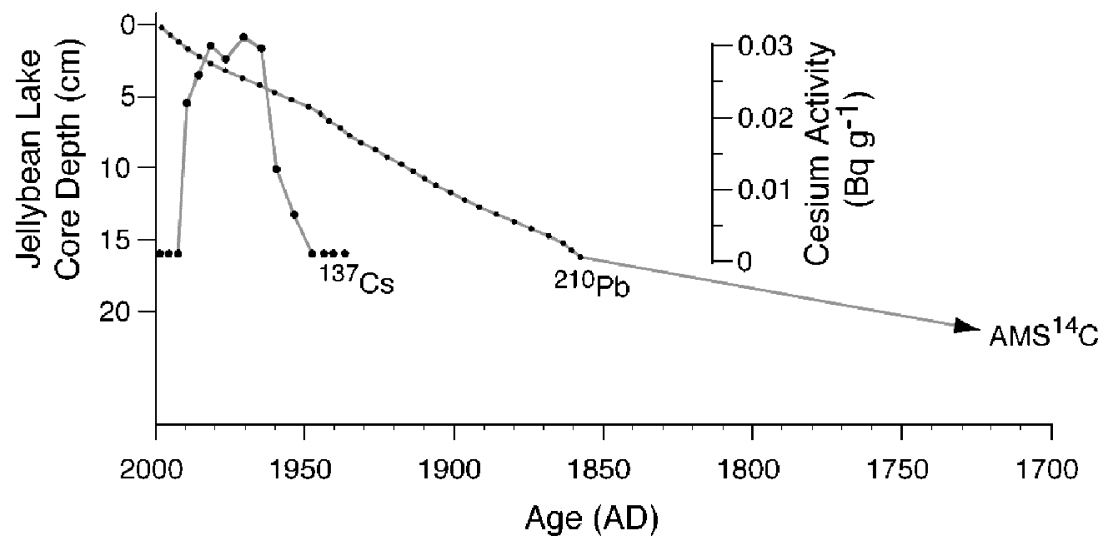

Figure 3. Jellybean Lake surface-sediment ${ }^{210} \mathrm{~Pb}$ ages from a constant rate of supply (CRS) age model shown with ${ }^{137} \mathrm{Cs}$ activity levels indicating that the site where core $\mathrm{C}$ was recovered has a constant sedimentation rate and that surface sediments are undisturbed.

sampled within a few $\mathrm{km}$ of Jellybean Lake (-21.5\%; Table 2). Since groundwater dynamics tend to smooth the effects of individual rainstorms and seasonal variations, groundwater- $\delta{ }^{18} \mathrm{O}$ tends to reflect mean annual isotope composition of precipitation (Gonfiantini et al., 1998; Ingraham, 1998; Tables 1 and 2).

We conducted a survey of the oxygen and hydrogen isotope ratios of water throughout the southern Yukon to compare Jellybean Lake water with precipitation, springs, rivers, and other lakes in the region (Fig. 5; Table 2). Hydrologically closed lakes in this region are strongly influenced by evaporation as indicated by relatively $\delta^{18} \mathrm{O}$ enriched isotope values. The precipitation data from
Whitehorse and Mayo were used to define the local meteoric water line (LMWL) and has a slope of $\sim 6$. The LMWL has a slightly lower slope than the global meteoric water line (GWML) which has a slope of $\sim 8$. Surface water from lakes in the Yukon defines a local evaporation line (LEL) with a slope of $\sim 4$. The LEL has a lower slope than the LMWL and GMWL because diffusion controlled isotopic fractionation that occurs during evaporation causes greater ${ }^{18} \mathrm{O}-{ }^{16} \mathrm{O}$ separations than ${ }^{2} \mathrm{H}-{ }^{1} \mathrm{H}$. Most evaporationsensitive lakes have $\delta^{18} \mathrm{O}$ values ranging between $-14 \%$ and $-7.7 \%$. In contrast, most evaporation-insensitive lakes such as Jellybean Lake have more depleted $\delta^{18} \mathrm{O}$ values ranging between $-22 \%$ and $-17 \%$. The intersection point

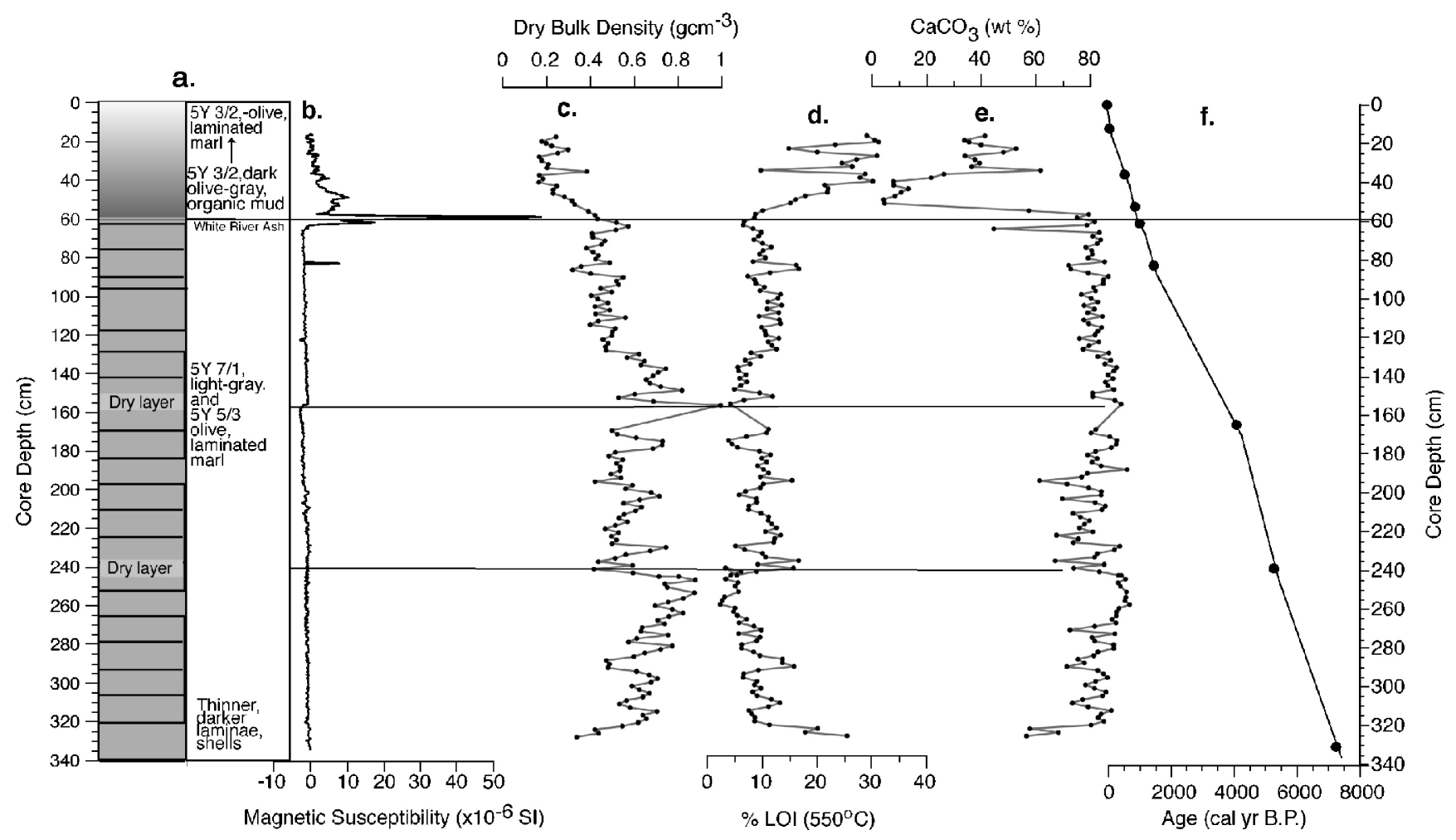

Figure 4. Jellybean Lake core properties including (a) sediment stratigraphy, (b) magnetic susceptibility, (c) dry bulk density, (d) $\% \mathrm{LOI}$ at $550^{\circ} \mathrm{C}$, (e) weight percent calcium carbonate, and (f) median-calibrated ages plotted against depth. 

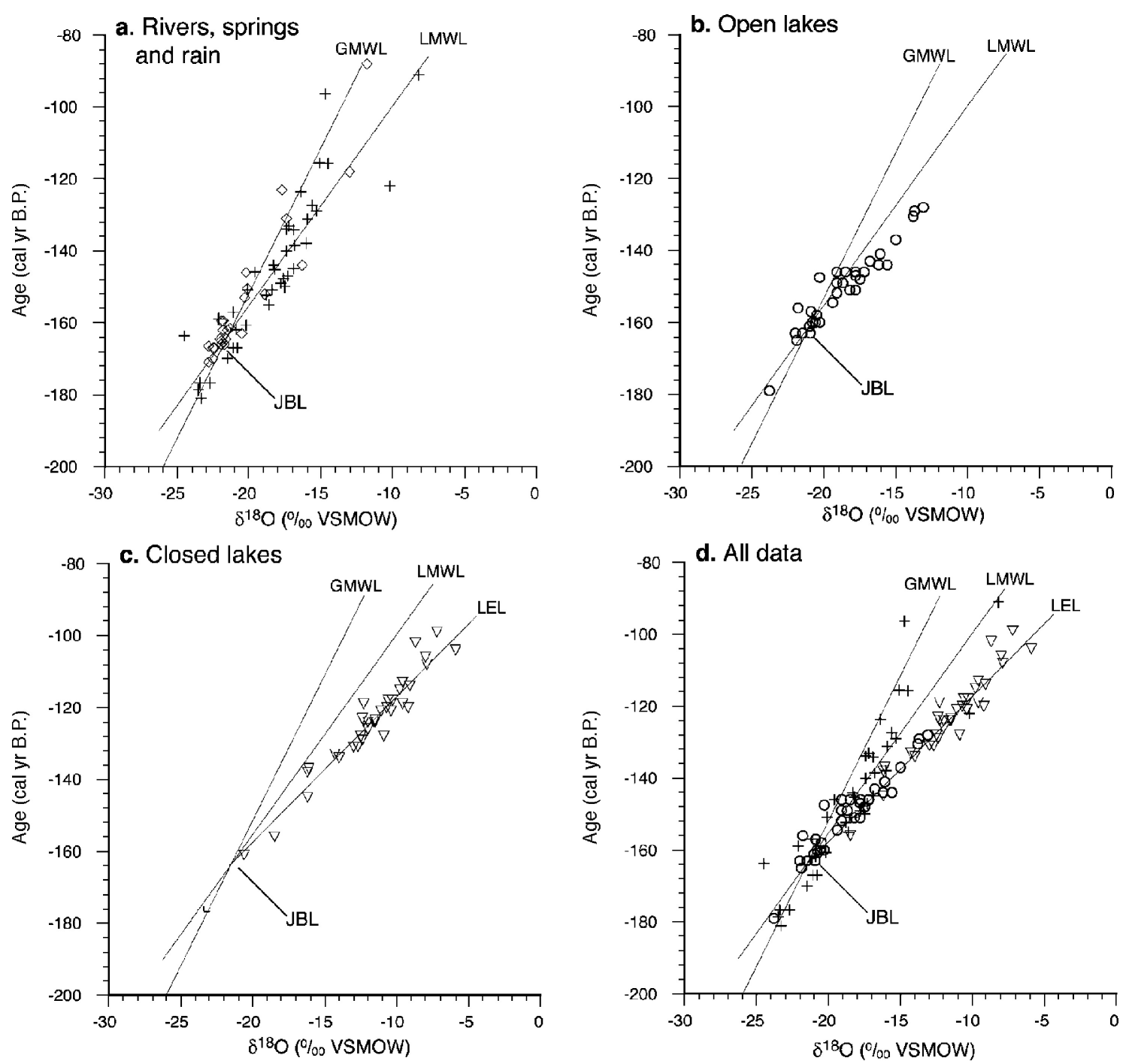

Figure 5. Oxygen and hydrogen isotope ratios of 71 surface water and precipitation samples from the southern Yukon Territory including Jellybean Lake (JBL) (sampling locations in Anderson, 2005): (a) precipitation from Mayo and Whitehorse (crosses) (IAEA/WMO, 2001), and rivers, groundwater, or springs (open diamonds). GMWL is the global meteoric water line (Rozanski et al., 1992). LMWL is the local meteoric water line, a linear regression of Mayo and Whitehorse data; (b) hydrologically open lakes (open circles), (c) hydrologically closed lakes (open triangles). The LEL is the local evaporation line, a linear regression of the lake data; (d) all data.

of the LEL and LMWL defines the average isotope values for unmodified mean annual precipitation and corresponds with our data for groundwater and Jellybean Lake.

Taken together, the strong similarities between Jellybean Lake $\delta^{18} \mathrm{O}$ and regional groundwater, precipitation, and other hydrologically open lakes suggest that despite its small catchment and lack of surface inflow or outflow, Jellybean Lake acts as an evaporation-insensitive lake. Subsurface inflow and outflow must be rapid enough to prevent significant evaporative enrichment above the regional average of precipitation and groundwater $\delta^{18} \mathrm{O}$ values. Jellybean Lake water $\delta^{18} \mathrm{O}$ is therefore a good representative of regional precipitation. Surface sediment carbonate in Jellybean Lake is in isotopic equilibrium with lake water $\delta^{18} \mathrm{O}$ as indicated by the temperature equation of Epstein et al. (1953). The predicted surface water value for $\delta^{18} \mathrm{O}_{\mathrm{Ca}}$ at $14.8^{\circ} \mathrm{C}$ of $-20.3 \%$ (VPDB) is very similar to the measured $\delta^{18} \mathrm{O}_{\mathrm{Ca}}$ value of $-19.9 \%$ (VPDB; Table 3).

\section{Core sedimentology}

A suite of multi-proxy sedimentary analyses was performed on cores from Jellybean Lake to document changes in paleolimnology and evaluate controls on the isotope data. The $340-\mathrm{cm}$ sediment stratigraphy is primarily composed of olive to light gray laminated marl with minor mineral matter, reflected by low magnetic susceptibility and dry bulk density (Fig. 4). The White River tephra at $64 \mathrm{~cm}$ (1150 cal yr B.P.; Clague et al., 1995) is easily identified both visually and by a sharp increase in magnetic susceptibility $(\sim 60 \mathrm{SI})$. The calcium carbonate content varies between $80 \%$ and $85 \%$. Sedimentary laminations are 
typically between 0.25 - and $1.0-\mathrm{cm}$ thickness. Smear slide analyses indicate that the color variations between laminae are caused by changes in the relative proportion of organic carbon and calcium carbonate content. The lake water is clear (Secchi disk depths $>8 \mathrm{~m}$ ) and calcite crystals form within the water column when photosynthetic activity alters the bicarbonate equilibrium during intense periods of productivity. Smear slide studies of the sediments show that they are nearly pure authigenic micrite. Other carbonate components such as ostracode tests, charophyte encrustations, mollusks, and gastropod shells were not observed in the nearly pure fine-grained calcium carbonate muds with the exception of some gastropods in the lowermost $15 \mathrm{~cm}$.

Sedimentary color, texture, and composition variations are generally consistent throughout the core. The only exception is where $\sim 30 \mathrm{~cm}$ of sediment overlying the White River tephra at $64 \mathrm{~cm}$ depth are darker and more faintly laminated. Calcium carbonate weight percentages decrease to less than $5 \%$ and organic carbon increases by $\sim 30 \%$. Magnetic susceptibility values are slightly higher, reflecting a higher proportion of mineral material that was also evident in smear slide observations. Nevertheless, by $\sim 34 \mathrm{~cm}-$ depth, calcium carbonate concentrations recover to $>30 \%$ and range from $\sim 40 \%$ to $60 \%$ to the core top. The uniform character of the sediments throughout the majority of the core suggests that physical and chemical characteristics similar to the modern lake have been stable for the last $\sim 7500 \mathrm{yr}$.

In addition to the evidence for inter-annual water level variations observed at Jellybean Lake today, there is sedimentary evidence for lake level changes in the past. There are two visible changes in the sediments to pelletized marl between $150-160 \mathrm{~cm}$ and $240-250 \mathrm{~cm}$ (Fig. 4). Such pelletized marls were noted on sub-aerial shoreline surfaces around the lake today. There are minor changes in the bulk density within these intervals, but organic carbon and calcium carbonate content are not significantly altered. If these layers were formed during lower lake levels, with possible sub-aerial exposure, neither the oxygen isotope values nor the sediment accumulation rates appear to have been affected (Fig. 6). The events were either sufficiently brief and/or the open-hydrological status of the lake remained unaffected because these periods were not registered in the $\delta^{18} \mathrm{O}_{\text {ca }}$ record.

\section{Oxygen and carbon isotopes}

Oxygen isotope values of sedimentary carbonate vary between $-18.5 \%$ and $-20.5 \%$ (Figs. 2 and 6; Table 1 ). Carbon isotopes have a larger range of variability $(\sim 4.5 \%)$ and are relatively ${ }^{13} \mathrm{C}$-depleted $(-3.5 \%$ o to $-7.5 \%)$. The oxygen and carbon isotopes are poorly correlated $(r=0.24)$, a general characteristic of carbonates formed in open lake systems (Talbot, 1990). However, both the $\delta^{18} \mathrm{O}_{\mathrm{Ca}}$ and $\delta^{13} \mathrm{C}_{\mathrm{Ca}}$ rapidly decrease near the White River tephra at 64 $\mathrm{cm}$. Close examination of the data indicates that $\delta^{18} \mathrm{O}_{\mathrm{Ca}}$ began to deplete before deposition of the tephra, while the $\delta^{13} \mathrm{C}_{\mathrm{Ca}}$ depletion occurred after the tephra was deposited. Thereafter, $\delta{ }^{13} \mathrm{C}_{\mathrm{Ca}}$ values increased more slowly than $\delta^{18} \mathrm{O}_{\mathrm{Ca}}$ values.

\section{Discussion}

\section{Carbon isotopes}

Carbon isotopes of lacustrine carbonate $\left(\delta^{13} \mathrm{C}_{\mathrm{Ca}}\right)$ reflect the isotopic composition of dissolved inorganic carbon (DIC). DIC is in turn a reflection of the balance between sources in groundwater and precipitation, atmospheric exchange, and $p \mathrm{CO}_{2}$ derived from respiration of isotopically depleted organic matter within the lake and its water sources (Dean and Stuiver, 1993; Herczeg and Fairbanks, 1987; McKenzie, 1985; Oana and Deevey, 1960; Siegenthaler and Eicher, 1986). Changes in $\delta^{13} \mathrm{C}_{\mathrm{Ca}}$ may reflect changes in rates of biological productivity, atmospheric $\mathrm{CO}_{2}$ exchange within the lake, stratification, hydrology, or some combination of all of these factors, which may be directly or indirectly related to climatic change. Jellybean $\delta^{13} \mathrm{C}_{\mathrm{Ca}}$ values $(-3 \%$ to $-7.5 \%$ ) are typical of productive lakes. Groundwater generally has relatively depleted values between $-10 \%$ and $-15 \%$, while exchange with atmospheric $\mathrm{CO}_{2}$ via mixing and photosynthesis leads to DIC ${ }^{13} \mathrm{C}$ enrichement. The relatively depleted carbon isotope values of Jellybean Lake DIC probably represent the signature of ${ }^{13} \mathrm{C}$-depleted groundwater that is subsequently modified by biological productivity and atmospheric exchange.

The decrease in $\delta^{13} \mathrm{C}_{\mathrm{Ca}}$ values above the White River tephra suggests a shift in biological activity and watershed run-off. The tephra could have lowered lake $\mathrm{pH}$ and increased turbidity. These changes might have lead to decreased photosynthesis, decreased carbonate production, and/or increased carbonate dissolution (Figs. 4 and 6) and explain why $\delta^{13} \mathrm{C}_{\mathrm{Ca}}$ recovery is notably longer than $\delta^{18} \mathrm{O}_{\mathrm{Ca}}$. Increased clastic sedimentation during this interval suggests that vegetation around the watershed was diminished and more clastic sediment was mobilized during precipitation events and/or spring run-off. The carbon isotope response to the White River tephra illustrates the complications associated with a direct climatic interpretation of $\delta^{13} \mathrm{C}_{\mathrm{Ca}}$ in Jellybean Lake. Therefore, we chose to use the oxygen isotope data for climatic interpretations.

\section{Oxygen isotopes}

Our results from water samples collected from a range of hydrological settings across the region suggest that variations in the oxygen isotope composition of precipitation $\left(\delta^{18} \mathrm{O}_{\mathrm{p}}\right)$ are responsible for driving the observed changes in Jellybean Lake $\delta^{18} \mathrm{O}$ and of the calcite formed in that lake water $\left(\delta^{18} \mathrm{O}_{\mathrm{Ca}}\right)$. What then controls temporal variation in the 
a.

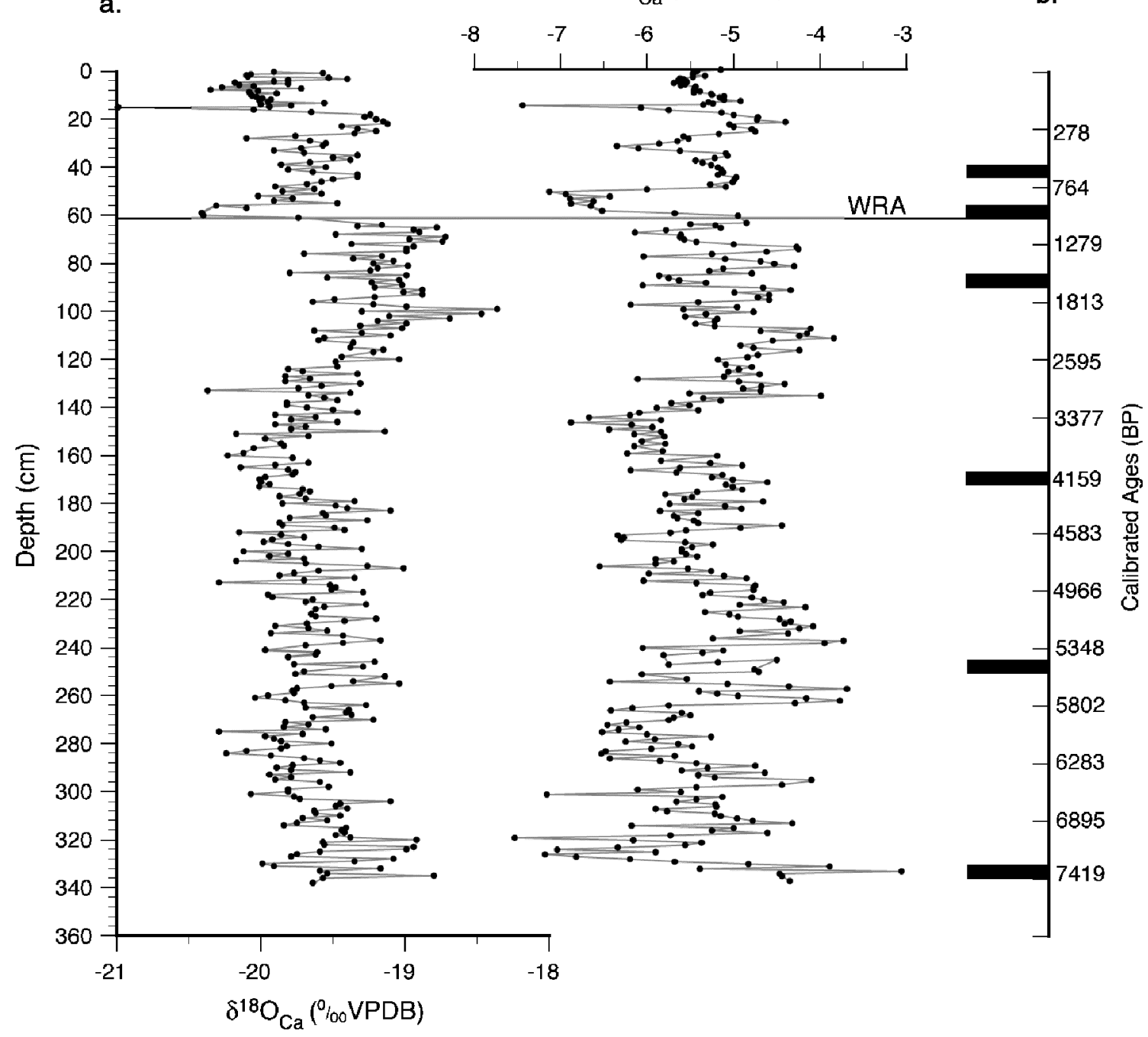

Figure 6. Jellybean Lake $\delta{ }^{18} \mathrm{O}_{\mathrm{Ca}}$ and $\delta^{13} \mathrm{C}_{\mathrm{Ca}}$ plotted on a (a) depth scale (cm) and (b) calibrated age scale (cal yr B.P.). Black bars indicate depths of radiocarbon ages. The horizontal line at $64 \mathrm{~cm}$ depth is the stratigraphic position of the White River tephra (Clague et al., 1995).

$\delta^{18} \mathrm{O}_{\mathrm{p}}$ in the region? Holdsworth et al. (1992) explored the relationship between $\delta^{18} \mathrm{O}_{\mathrm{p}}$ and temperature in the Northwest Pacific. They found that the Mt. Logan Summit ice core $\delta^{18} \mathrm{O}(5340 \mathrm{~m}$ a.s.l) was not significantly correlated with instrumental temperature records or paleotemperatures inferred from dendrochronologies. The $\delta^{18} \mathrm{O}$ data from the Eclipse ice core on Mount Logan (3017 m a.s.1.) have a weak correlation with temperature, explaining only $10-$ $15 \%$ of the variance (Wake et al., 2002).

The average relation for middle and high latitudes between $\delta^{18} \mathrm{O}_{\mathrm{p}}$ and mean annual surface temperature is $\sim 0.6 \%$ per ${ }^{\circ} \mathrm{C}$ (Dansgaard, 1964; Rozanski et al., 1992). Combining this factor with the fractionation coefficient for calcite formation and lake water temperature, $-0.25 \%$ per ${ }^{\circ} \mathrm{C}$ (Friedman and O'Niel, 1977), leads to an estimated change in $\delta^{18} \mathrm{O}_{\mathrm{Ca}}$ of $\sim 0.35 \%$ per ${ }^{\circ} \mathrm{C}$ of atmospheric temperature change for Jellybean Lake (e.g., Anderson et al., 2001; Yu et al., 1997). The observed range of $\delta^{18} \mathrm{O}_{\mathrm{Ca}}$ in Jellybean Lake is $\sim 2.0 \%$ (Fig. 6), corresponding to a temperature range of $\sim 5.7^{\circ} \mathrm{C}$ which we consider to be too large for this period based on comparison with other regional paleorecords (Heusser et al., 1985; Hu et al., 2001). In addition, the abrupt $\delta^{18} \mathrm{O}_{\mathrm{Ca}}$ shifts during the last $1500 \mathrm{yr}$ are up to $1.5 \%$, which would correspond to a change of $\sim 4.3^{\circ} \mathrm{C}$. These large inferred temperature changes, combined with the poor correlation between Jellybean Lake $\delta^{18} \mathrm{O}_{\mathrm{Ca}}$ and a 300 -yr dendrochronology record from the Mackenzie River delta, interpreted to reflect growing season temperatures for the region (Szeicz and MacDonald, 1995, 1996), suggest that temperature is not the primary control. Furthermore, isotope-modeling studies by Bowen and Wilkinson (2002) identify northwestern Canada as an area where $\delta^{18} \mathrm{O}_{\mathrm{p}}$ has high magnitude deviations from typical temperature controlled relationships. Based on these observations, we conclude that multi-annual $\delta^{18} \mathrm{O}_{\mathrm{p}}$ variation in this region is not driven by temperature changes alone. We suggest that temporal changes in atmospheric circulation across the St. Elias Mountains are the major control on the 
oxygen isotope composition of precipitation in the interior of the southern Yukon and hence hydrologically open lakes such as Jellybean.

\section{Oxygen isotopes, precipitation, and atmospheric circulation}

Numerous oxygen isotope studies of sediment from evaporation-insensitive lakes have inferred past changes in atmospheric circulation (e.g., Edwards et al., 1996; Hammerlund et al., 2002; Jones et al., 2004; Rosqvist et al., 2004; Wolfe et al., 2003; Yu et al., 1997). Precipitation data show that maritime air masses reaching the coast of southwest Alaska are relatively ${ }^{18} \mathrm{O}$-enriched (Adak, $-8 \%$ o to $-11 \%$ ) compared to precipitation falling from these same air masses in the interior of the Yukon (Whitehorse, $-18 \%$ to $-21 \%$; IAEA/WMO, 2001). Such large depletions occur because of the effects of Rayleigh distillation during air mass uplift, rainout, and transport across the average 3000-m-high topographic barrier of the St. Elias Mountains (Rozanski et al., 1993). We hypothesize that changes in air mass trajectory and the intensity of moisture transport through time across the St. Elias Mountains control the mean annual isotopic value of precipitation falling in the interior of the Yukon. A likely mechanism is multi-decadal fluctuations in the location and strength of the AL that directs maritime air masses into the interior with varying effects on fractionation during transport.

The NP index (NPI) represents changes in AL position and strength (Trenbirth and Hurrell, 1994). Figure 7 shows the normalized Jellybean Lake $\delta^{18} \mathrm{O}_{\mathrm{Ca}}$-record for the last $100 \mathrm{yr}$ compared with the NP index. Although the NPI is calculated for each year, the Jellybean data are integrations of 3-6 yr during the 20th century that are not regularly spaced in time. We used the 5-yr running average of the NPI to identify anomaly values for the $23 \mathrm{yr}$ that corresponded with the ${ }^{210} \mathrm{~Pb}$-determined ages for the sediment samples.
Correlation of the 23 pairs of data is significant at the 0.05 confidence level $(r=0.48)$ and accounts for a relatively small fraction of explained variance $\left(r^{2}=0.23\right)$. However, a relatively low correlation might be expected given the uncertainties in our age model and the nature of the signals being recorded. The NPI is a seasonal signal because the AL is strongest in the winter and diminishes during the summer. The Jellybean Lake- $\delta{ }^{18} \mathrm{O}_{\mathrm{Ca}}$ data represent an integration over 3- to 6-yr periods and reflects groundwater- $\delta^{18} \mathrm{O}$ which tends to smooth the effects of seasonal variations. It may be that this multi-annual $\delta^{18} \mathrm{O}_{\mathrm{p}}$ signal is predominantly influenced by variability in fall and winter precipitation. A similar effect has been observed for inter-annual ice accumulation on Mt. Logan where only winters of high accumulation were found to have a strong connection with atmospheric circulation (Rupper et al., 2004). If this assessment is correct and the limitations of the isotope time series are kept in mind, then the correlation can be seen as supporting a relationship between Jellybean Lake- $\delta^{18} \mathrm{O}_{\mathrm{Ca}}$ and $\mathrm{AL}$ intensity/position.

Observations between 1976 and 1988 A.D. show the AL was more intense and shifted eastward, advecting warm moist air along the northwest Pacific coast from the southsoutheast, leading to increased coastal precipitation (Cayan and Peterson, 1989; Mantua et al., 1997; Trenbirth and Hurrell, 1994). During this period Jellybean Lake $\delta^{18} \mathrm{O}_{\mathrm{Ca}}$ values were relatively depleted. We propose that when the $\mathrm{AL}$ is eastward and/or stronger, the effects of Raleigh distillation are enhanced and precipitation reaching the interior is more depleted. An eastward and/or intensified AL (negative NPI anomaly) delivers strong southerly winds directly into the mountain barrier trending northwest to southeast along the Alaskan coast. It is possible that such an orientation in moisture flow, directly into the large mountains, would enhance rainout on the coastal side. Consequently, more fractionated vapor is vigorously forced

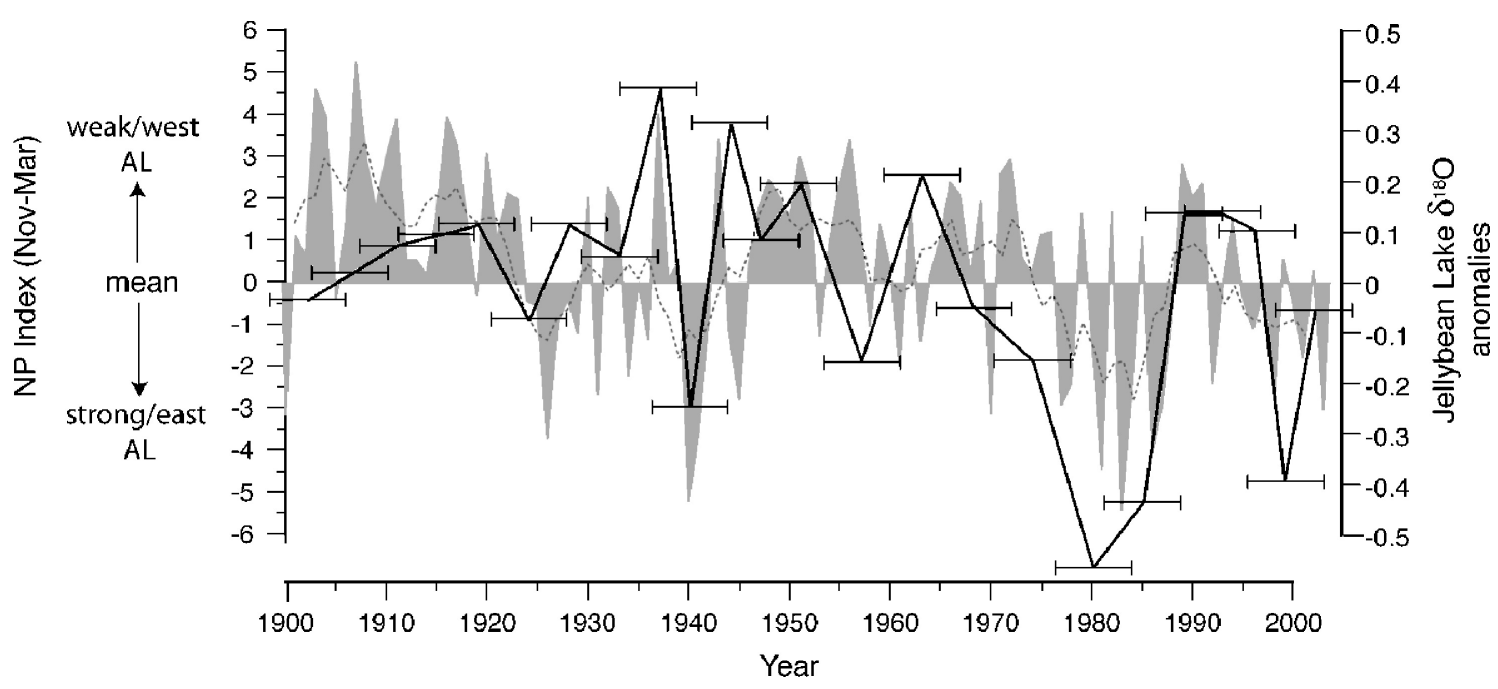

Figure 7. Normalized Jellybean Lake $\delta^{18} \mathrm{O}_{\mathrm{Ca}}$ data (black line) are shown with the NP index since 1900 A.D. (gray shade is annual data, dashed line is 5 yr running average; Trenbirth and Hurrell, 1994). Negative NPI anomalies represent a strong/eastward Aleutian Low. Error bars on $\delta^{18} \mathrm{O}_{\mathrm{Ca}}$ data represent \pm 5 -yr age uncertainty based on the ${ }^{210} \mathrm{~Pb}$ and ${ }^{137} \mathrm{Cs}$ measurements (Fig. 3). 
up and over the barrier into the interior. Stronger leeward winds and an enhanced rain shadow effect would lead to further fractionation of the reduced amount of precipitation reaching the interior Yukon (Table 4).

In contrast, when the $\mathrm{AL}$ is westward and/or weaker, fractionation is decreased during transport and $\delta^{18} \mathrm{O}_{\mathrm{p}}$ is relatively ${ }^{18} \mathrm{O}$-enriched. Historically, positive NPI anomalies represented a weaker and/or westward position of the AL. This causes less vigorous meridional moisture transport from the south-southeast along the northwest Pacific coast and allows more moisture flow from the Bearing Sea, to the west, into interior Alaska. During positive NPI anomalies, Jellybean Lake $\delta^{18} \mathrm{O}_{\mathrm{Ca}}$ is relatively enriched, reflecting decreased fractionation of precipitation during transport. A more zonal flow pattern and westerly moisture trajectory is able to move more parallel to the coastal mountain barrier and may avoid the same degree of uplift, cooling, and rainout than when moisture flow is more directly into the mountain barrier. In this case, less fractionated moisture would be more likely to infiltrate the northeast-southwest trending valleys leading into the interior of the Yukon (Streten, 1974). We infer that the primary control on $\delta^{18} \mathrm{O}_{\mathrm{p}}$ in the southwest Yukon is temporally changing moisture trajectories into and over the coastal mountains driven by the strength and the position of the AL. Assuming this is correct, the $\delta^{18} \mathrm{O}_{\mathrm{Ca}}$ from Jellybean Lake provides a record of Holocene changes in intensity and/ or position of the AL (Fig. 8).

\section{Holocene paleoclimate}

The Jellybean Lake $\delta^{18} \mathrm{O}_{\mathrm{Ca}}$ record provides Holocene paleoclimatic information at higher temporal resolution than available from previous work (Fig. 8). While the comparison of sediment core to instrumental climate data suggests a relationship between lake $\delta^{18} \mathrm{O}_{\mathrm{Ca}}$ and characteristics of the $\mathrm{AL}$, such as defined by the NPI, it is important to recognize that data from regional networks of sites are necessary to unambiguously distinguish between changes in AL strength and position over time. Keeping this limitation in mind in interpreting the isotopic record, the data suggest that $\mathrm{AL}$

Table 4

Relationships between Aleutian Low, $\delta^{18} \mathrm{O}$, Gulf of Alaska, and Alaskan salmon

\begin{tabular}{lll}
\hline Aleutian Low intensity $\left(\mathrm{NP}\right.$ Index $\left.{ }^{\mathrm{a}}\right)$ & Strong $(-)$ & Weak $(+)$ \\
\hline $\begin{array}{l}\text { Oxygen isotope fractionation during } \\
\text { transport to southern interior Yukon }\end{array}$ & More & Less \\
SW-interior Yukon $\delta^{18} \mathrm{O}_{\mathrm{p}}$ & ${ }^{18} \mathrm{O}$-depleted & ${ }^{18} \mathrm{O}$-enriched \\
Jellybean Lake $\delta^{18} \mathrm{O}_{\mathrm{Ca}}$ & ${ }^{18} \mathrm{O}$-depleted & ${ }^{18} \mathrm{O}$-enriched \\
Gulf of Alaska boundary currents & Strong & Weak \\
Gulf of Alaska SSTs & Warm & Cold \\
Alaskan salmon abundance & Higher & Lower \\
Karluk Lake $\delta^{15} \mathrm{~N}^{\mathrm{c}}$ & ${ }^{15} \mathrm{~N}$-enriched & ${ }^{15} \mathrm{~N}$-depleted \\
\hline
\end{tabular}

${ }^{a}$ Trenbirth and Hurrell (1994).

${ }^{\mathrm{b}}$ Mantua et al. (1997).

${ }^{\mathrm{c}}$ Finney et al. (2002). position and strength during the early to middle Holocene, $7500-4500$ cal yr B.P., was generally weaker than and/or westward from today's location. Between $\sim 4500$ and 3500 cal yr B.P., circulation intensified and was similar to today, with airflow predominantly from the southwest (Wahl et al., 1987). After $\sim 3500$ cal yr B.P. a steady trend towards enriched $\delta^{18} \mathrm{O}_{\mathrm{Ca}}$ reflects a westward and/or weaker AL. By $\sim 2000$ cal yr B.P. the AL position was on average farther west and/or weaker than any time during the last $\sim 7500 \mathrm{yr}$. Other paleoclimatic studies report greater effective moisture in the central and southern Yukon prior to $\sim 2000 \mathrm{cal}$ yr B.P. (Pienitz et al., 2000). These observations are consistent with the isotope results from Jellybean Lake. Previous studies of regional synoptic climatology suggest that a weaker/westward positioned $\mathrm{AL}$ is related to increased moisture delivery to interior regions (Edwards et al., 2001).

Our record also suggests that abrupt changes in $\mathrm{AL}$ position/strength were more frequent during the last $\sim 2000$ yr than the preceding period. The decreases in $\delta^{18} \mathrm{O}_{\mathrm{Ca}}$ $\sim 1200$ cal yr B.P. represent rapid eastward shifts and/or intensification of the AL. Between $\sim 500$ and $300 \mathrm{cal} \mathrm{yr}$ B.P., $\delta^{18} \mathrm{O}_{\mathrm{Ca}}$ became relatively enriched again, reflecting a westward shift and/or weakening. Another easterly shift and/or intensification $\sim 1700$ A.D. correspond with cooler spring and summer south coastal land temperatures (Wiles et al., 1998). AL variability since 1900 A.D. indicates a weak/westward period in the early part of the century that corresponds with the termination of south coastal glacial advances and the end of the Little Ice Age (Wiles et al., 1999).

The oxygen isotope evidence presented here suggests high frequency changes in AL location/strength have occurred throughout the Holocene. However, the largest secular changes occurred after $\sim 3500$ cal yr B.P. Large changes in AL intensity and position have been shown to be accompanied by changes in ocean circulation and sea surface temperatures that would likely effect marine ecosystems (Mantua et al., 1997). Salmon catch records during the 20th century suggest a correlation between the eastward shifted and strong AL between 1976 to 1988 A.D. and increased production of Alaskan salmon (Hare and Francis, 1994; Mann et al., 1998). A reconstruction of Alaskan sockeye salmon abundance indicates a prominent multi-century change from lower to higher average abundance $\sim 1200$ cal yr B.P. (Finney et al., 2002; Fig. 8). This increase corresponds with an eastward and/or intensified AL indicated by Jellybean Lake $\delta^{18} \mathrm{O}_{\mathrm{Ca}}$. Similarly, a multidecade decline in salmon abundance in the early 19th century (Finney et al., 2000) coincides with a westward and/ or weaker AL. The record from Jellybean Lake reflecting changes in AL position/strength is consistent in terms of the timing and direction with late Holocene changes in Alaskan salmon abundance.

Neoglaciation was initiated in the St. Elias and Coast Mountains $\sim 3400$ cal yr B.P. (Calkin et al., 2001; Denton and Karlen, 1977; Fig. 8) and broadly corresponds with a 


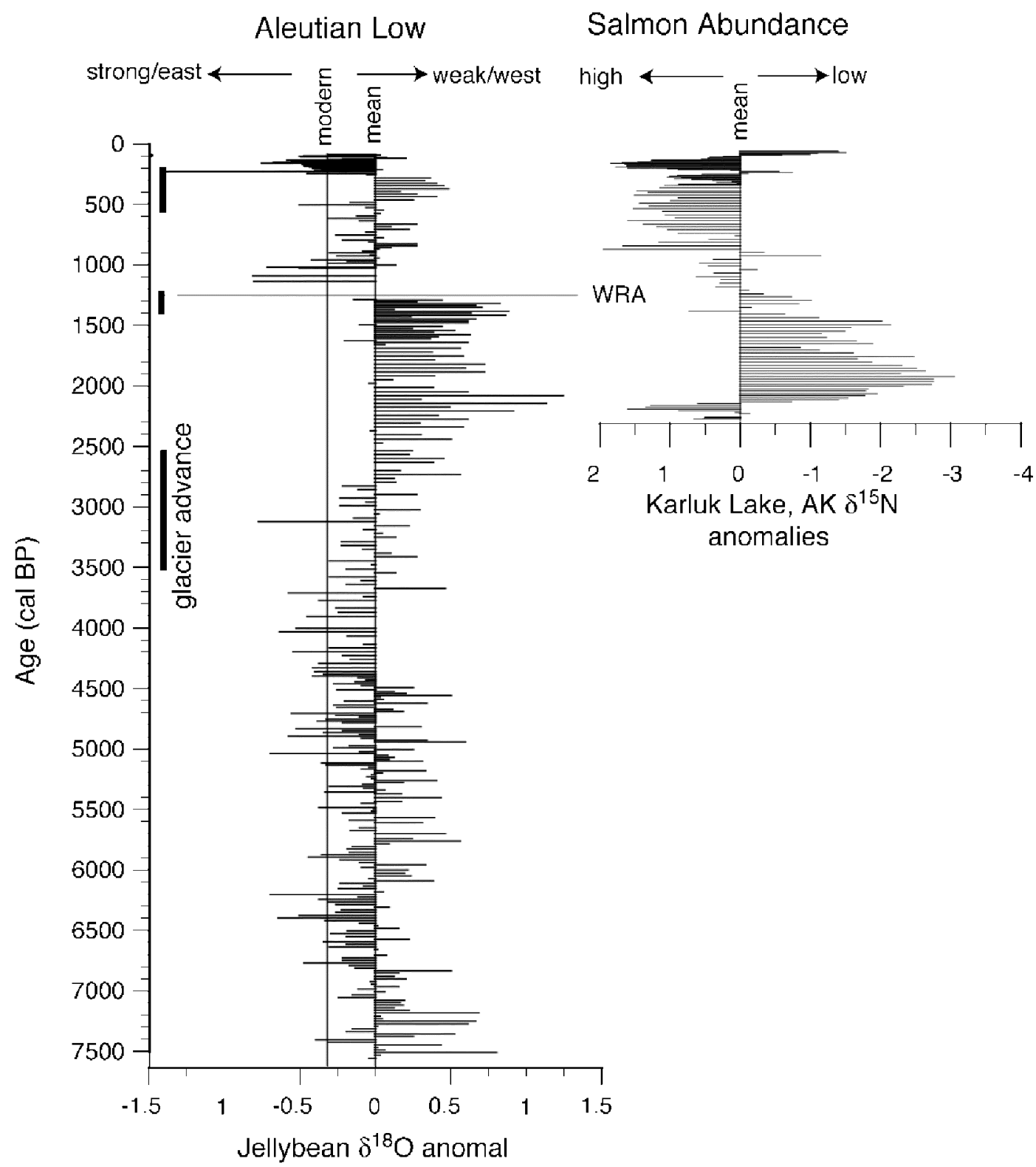

Figure 8. Normalized Jellybean Lake $\delta^{18} \mathrm{O}_{\mathrm{Ca}}$ is shown with sedimentary- $\delta{ }^{15} \mathrm{~N}$ from Karluk Lake, Alaska, since 2200 cal yr B.P. (Finney et al., 2002). $\delta^{15} \mathrm{~N}$ is a proxy for sockeye salmon abundance where enriched $\delta^{15} \mathrm{~N}$ records periods of higher salmon abundance (Finney et al., 2000). Note that changes during the 20th century also reflect the influence of commercial fishing in addition to that of climate. Timing of glacier advances in the St. Elias Mountains is indicated by vertical bars (Denton and Karlen, 1977). Vertical line on $\delta^{18} \mathrm{O}_{\mathrm{Ca}}$ scale labeled 'modern' is an average of the last $30 \mathrm{yr}$ of data. WRA indicates the stratigraphic position of the White River tephra.

period when the $\mathrm{AL}$ was eastward and/or stronger before a shift westwards and/or weakening after $\sim 3000 \mathrm{cal}$ yr B.P. The onset of Neoglaciation may also be attributed to decreasing solar insolation in addition to changes in the seasonality of precipitation. Increased moisture delivery during winter by an intensified/eastward AL could lead to coastal glacier advances (e.g., Heusser et al., 1985). Our results are consistent with other studies that suggest neoglacial climate corresponds with secular shifts to an intensified/eastward AL and increasing moisture delivery to coastal glaciers and the St. Elias and Coast Mountains (e.g., Heusser et al., 1985).
The oxygen isotope data indicate that changes in the intensity of the AL during the early and middle Holocene differed from the late Holocene. Dyke and Savelle (2000) noted a similar circulation change over in the western Arctic Ocean. During the middle and early Holocene, the Beaufort Gyre was positioned either farther west than it is today or had intensified. After $\sim 2000$ cal yr B.P., it weakened and contracted or moved. The effect was reduced summer sea-ice extent that may have enticed the eastward migration of bowhead whales and possibly the Thule culture (Dyke and Savelle, 2000, 2001). Around 1200 cal yr B.P. a trend toward an intensified/eastward AL began 
and subsequent $\mathrm{AL}$ variability was rapid and more frequent. When the Beaufort Gyre and associated anticyclonic atmospheric circulation around the polar vortex weakened and contracted, the AL strengthened. The oxygen isotope record presented here is consistent with other regional records of natural climate variability, connecting two prominent high-latitude atmospheric and oceanic circulation features in the western Canadian Arctic and North Pacific region.

\section{Acknowledgments}

We thank Mary E. Edwards, Mathias Viulle, and Carsten Braun for helpful discussions during the preparation of this paper. We also thank Britt Haugen, Dan Nelson, Joe Rodgers, and Nathan Stansell for their kind assistance in the field. Finally we thank Eric Steig, Summer Rupper, and an anonymous reviewer for constructive comments that improved the paper. The National Science Foundation (ATM-0296157 and ATM-0097127) and the Department of Geosciences of the University of Massachusetts Amherst supported this work.

\section{References}

Anderson, L., 2005. Holocene climate of the southwest Yukon Territory, Canada, inferred from lake-level and isotope analyses of small carbonate lakes. Ph.D. Dissertation, University of Massachusetts Amherst, Department of Geosciences, Amherst, MA, USA.

Anderson, L., Abbott, M.B., Finney, B.P., 2001. Holocene climate inferred from oxygen isotope ratios in lake sediments, Central Brooks Range, Alaska. Quaternary Research 55, 313-321.

Appleby, P.G., 2001. Chronostratigraphic techniques in recent sediments. In: Last, W., Smol, J.P. (Eds.), Tracking Environmental Change Using Lake Sediments, Basin Analysis, Coring, and Chronological Techniques vol. 1. Kluwer Academic Press, Dordrecht, pp. 171-203.

Bengtsson, L., Enell, M., 1986. Chemical analyses. In: Berglund, B.E. (Ed.), Handbook of Holocene Paleoecology and Paleohydrology. J. Wiley, Chichester, pp. 423-451.

Biondi, F., Gershunov, A., Cayan, D.R., 2001. North Pacific decadal climate variability since 1661 . Journal of Climate 14, 5-10.

Bitz, C.M., Battisti, D.S., 1999. Interannual to decadal variability in climate and the glacier mass balance in Washington, Western Canada and Alaska. Journal of Climate 12, 3181-3196.

Bowen, G.J., Wilkinson, B., 2002. Spatial distribution of $\delta^{18} \mathrm{O}$ in meteoric precipitation. Geology 30, 315-318.

Brown, T.A., Nelson, D.E., Mathewes, R.W., Vogel, J.S., Southon, J.R., 1989. Radiocarbon dating of pollen by accelerator mass spectrometry. Quaternary Research 32, 205-212.

Calkin, P.E., Wiles, G.C., Barclay, D.J., 2001. Holocene coastal glaciation of Alaska. Quaternary Science Reviews 20, 449-461.

Cayan, D.R., Peterson, D.H., 1989. The influence of North Pacific atmospheric circulation on streamflow in the west. Geophysical Monograph 55, 375-379.

Clague, J.J., Evans, S.G., Rampton, V.N., Woodsworth, G.J., 1995. Improved age estimates for the White River and Bridge River tephras, Western Canada. Canadian Journal of Earth Sciences 32, 1172-1179.

Cwynar, L.C., 1988. Late Quaternary vegetation history of Kettlehole Pond, southwestern Yukon. Canadian Journal of Forest Research 18, $1270-1279$
Cwynar, L.C., Spear, R.W., 1995. Paleovegetation and paleoclimatic changes in the Yukon at $6 \mathrm{kA}$ BP. Geographie Physique et Quaternaire $49,29-35$.

Dansgaard, W., 1964. Stable isotopes in precipitation. Tellus 16, 436-468.

D’Arrigo, R., Wiles, G., Jacoby, G., Villaba, R., 1999. North Pacific sea surface temperatures: past variations inferred from tree rings. Geophysical Research Letters 26, 2757-2760.

Davi, N.K., Jacoby, G.C., Wiles, G.C., 2003. Boreal temperature variability inferred from maximum latewood density and tree-ring width data, Wrangell Mountain region, Alaska. Quaternary Research $60,252-262$

Dean, W.E., Stuiver, M., 1993. Stable carbon and oxygen isotope studies of the sediments of Elk Lake, Minnesota. In: Bradbury, J.P., Dean, W.F. (Eds.), Elk Lake, Minnesota: Evidence for Rapid Climate Change in the North-Central United States. United States Geological Survey Special Paper, vol. 276, pp. 163-180 (Boulder, Colorado).

Denton, G.H., Karlen, W., 1977. Holocene glacial and tree-line variations in the White River Valley and Skolai Pass, Alaska and Yukon Territory. Quaternary Research 7, 63-111.

Dyke, A.S., Savelle, J.M., 2000. Holocene driftwood incursion to Southwestern Victoria Island, Canadian Arctic Archipelago, and its significance to Paleoceanography and Archeology. Quaternary Research 54, $113-120$

Dyke, A.S., Savelle, J.M., 2001. Holocene history of the Bering Sea Bowhead whale (Balaena mysticetus) in its Beaufort Sea summer grounds off southwestern Victoria Island, western Canadian Arctic. Quaternary Research 55, 371-379.

Dyke, A.S., Andrews, J.T., Clark, P.U., England, J.H., Miller, G.H., Shaw, J., Veillette, J.J., 2002. The Laurentide and Innuitian ice sheets during the last glacial maximum. Quaternary Science Reviews $21,9-31$.

Edwards, T.W.D., Wolfe, B.B., MacDonald, G.M., 1996. Influence of changing atmospheric circulation on precipitation $\delta^{18} \mathrm{O}$-temperature relations in Canada during the Holocene. Quaternary Research 46, 211-218.

Edwards, M.E., Mock, C.J., Finney, B.P., Barber, V.A., Bartlein, P.J., 2001. Potential analogues for paleoclimatic variations in eastern interior Alaska during the past 14,000 yr: atmospheric-circulation controls of regional temperature and moisture responses. Quaternary Science Reviews 20, 189-202.

Environment Canada, 2003. Canadian Climate Normals Web site. http://www.msc-smc.ec.gc.ca/climate/climate_normals/index_e.cfm.

Epstein, S., Buchsbaum, R., Lowenstam, H.A., Urey, H.C., 1953. Revised carbonate-water temperature scale. Geological Society of America Bulletin 62, 417-426.

Finney, B.P., Gregory-Eaves, I., Sweetman, J., Douglas, M.S.V., Smol, J.P., 2000. Impacts of climatic change and fishing on Pacific salmon abundance over the past 300 years. Science 290, 795-799.

Finney, B.P., Gregory-Eaves, I., Douglas, M.S.V., Smol, J.P., 2002. Fisheries productivity in the northeastern Pacific Ocean over the past 2,200 years. Nature 416, 729-733.

Friedman, I., O'Niel, J.R., 1977. Compilation of stable isotope fractionation factors of geochemical interest. In: Fleischer, M. (Ed.), Data of Geochemistry, sixth ed. Chapter KK. United States Geological Survey Professional Paper 440-KK, Boulder, pp. 12

Gonfiantini, R., Frohlich, K., Araguas-Araguas, L., Rozanski, K., 1998. Isotopes in groundwater hydrology. In: Kendall, C., McDonnell, J.J. (Eds.), Isotope Tracers in Catchment Hydrology. Elsevier, Amsterdam, pp. 203-246.

Hammerlund, D., Barnekow, L., Birks, H.J.B., Buchardt, B., Edwards, T.W.D., 2002. Holocene changes in atmospheric circulation recorded in the oxygen-isotope stratigraphy of lacustrine carbonates from northern Sweden. The Holocene 12, 339-351.

Hammerlund, D., Björck, S., Buchardt, B., Israelson, C., Thomsen, C.T., 2003. Rapid hydrological changes during the Holocene revealed by stable isotope records of lacustrine carbonates from Lake Igelsjön, Southern Sweden. Quaternary Science Reviews 22, 353-370. 
Hare, S.R., Francis, R.C., 1994. Climate change and salmon production in the Northeast Pacific Ocean. In: Beamish, R.J. (Ed.), Climate Change and Northern Fish Populations, Canadian Special Publication in Fish and Aquatic Science vol. 121, pp. 1-33.

Heiri, O., Lotter, A.F., Lemcke, G., 2001. Loss on ignition as a method for estimating organic and carbonate content in sediments: reproducibility and comparability of results. Journal of Paleolimnology 25, 101-110.

Herczeg, A.L., Fairbanks, R.G., 1987. Anomalous carbon isotope fractionation between atmospheric $\mathrm{CO}_{2}$ and dissolved inorganic carbon induced by intense photosynthesis. Geochimica et Cosmochimica Acta $51,895-899$.

Heusser, C.J., Heusser, L.E., Peteet, D.M., 1985. Late-quaternary climatic change on the American North Pacific Coast. Nature 316, 485-487.

Holdsworth, G., Krouse, H.R., Nosal, M., 1992. Ice core climate signals from Mount Logan, Yukon A.D. 1700-1897. In: Bradley, R.S., Jones, P.D. (Eds.), Climate Since A.D. 500. Routelidge, London, pp. $483-516$.

Hu, F.S., Shemesh, A., 2003. A biogenic-silica $\delta^{18} \mathrm{O}$ record of climatic change during the last glacial-interglacial transition in southwestern Alaska. Quaternary Research 59, 379-385.

Hu, F.S., Ito, E., Brown, T.A., Curry, B.B., Engstron, D.R., 2001. Pronounced climatic variations in Alaska during the last two millennia. Proceedings of the National Academy of Sciences 98, 10552-10556.

Hu, F.S., Kaufman, D., Yoneji, S., Nelson, D., Shemesh, A., Huang, Y., Tian, J., Bond, G., Clegg, B., Brown, T., 2003. Cyclic variation and solar forcing of Holocene climate in the Alaskan subarctic. Science 301, $1890-1893$.

IAEA/WMO, 2001. Global Network of Isotopes in Precipitation (GNIP) and Isotope Hydrology Information System (ISOHIS). International Atomic Energy Agency and World Meteorological Organization. http://www.isohis.iaea.org/.

Ingraham, N.L., 1998. Isotopic variations in precipitation. In: Kendall, C., McDonnell, J.J. (Eds.), Isotope Tracers in Catchment Hydrology. Elsevier, Amsterdam, pp. 87-118.

Jones, V.J., Leng, M.J., Solovieva, N., Sloane, H.J., Tarasov, P., 2004. Holocene climate of the Kola Peninsula; evidence from the oxygen isotope record of diatom silica. Quaternary Science Reviews 23, $833-839$.

Keenan, T.J., Cwynar, L.C., 1992. Late Quaternary history of black spruce and grasslands in southwest Yukon Territory. Canadian Journal of Botany 70, 1336-1345.

Lacourse, T., Gajewski, K., 2000. Late Quaternary vegetation history of Sulfur Lake, southwest Yukon Territory, Canada. Arctic 53, 27-35.

Latif, M., Barnett, T.P., 1994. Causes of decadal climate variability over the North Pacific and North America. Science 266, 634-637.

Leng, M.J., Anderson, N.J., 2003. Isotopic variation in modern lake waters from western Greenland. The Holocene 13, 605-611.

Mann, D.H., Crowell, A.L., Hamilton, T.D., Finney, B.P., 1998. Holocene geologic and climatic history around the Gulf of Alaska. Arctic Anthropology 35, 112-131.

Mantua, N.J., Hare, S.R., Zhang, Y., Wallace, J.M., Francis, R.C., 1997. A Pacific interdecadal climate oscillation with impacts on salmon production. Bulletin of the American Meteorological Society 78, $1069-1079$.

McKenzie, J.A., 1985. Carbon isotopes and productivity in the lacustrine and marine environment. In: Strunn, W. (Ed.), Chemical Processes in Lakes. J. Wiley, Toronto, pp. 99-118.

Mock, C.J., Bartlein, P.J., Anderson, P.M., 1998. Atmospheric circulation patterns and spatial climatic variations in Beringia. International Journal of Climatology 18, 1085-1104.

Moore, G.W.K., Alverson, K., Holdsworth, G., 2002a. Variability in the climate of the Pacific Ocean and North America as expressed in the Mount Logan ice core. Annals of Glaciology 35, 423-429.

Moore, G.W.K., Holdsworth, G., Alverson, K., 2002b. Climate change in the North Pacific region over the past three centuries. Nature 420, $401-403$
Oana, S., Deevey, E.S., 1960. Carbon-13 in lake waters, and its possible bearing on paleolimnology. American Journal of Science 258-A, $253-272$.

Pienitz, R., Smol, J.P., Last, W.M., Leavitt, P.R., Cumming, B.F., 2000. Multi-proxy Holocene paleoclimatic record from a saline lake in the Canadian subarctic. The Holocene 10, 673-686.

Plummer, L.N., Busenberg, E., 1982. The solubility of calcite, aragonite, and vaterite in $\mathrm{CO}_{2}-\mathrm{H}_{2} \mathrm{O}$ solutions between 0 and $90^{\circ} \mathrm{C}$, and an evaluation of the aqueous model for $\mathrm{CaCO}_{3}-\mathrm{CO}_{2}-\mathrm{H}_{2} \mathrm{O}$ equilibria. Geochimica et Cosmochimica Acta 44, 1011-1040.

Rosqvist, G., Jonsson, C., Yam, R., Karlén, W., Shemesh, A., 2004. Diatom oxygen isotopes in pro-glacial lake sediments from northern Sweden: a 5000 year record of atmospheric circulation. Quaternary Science Reviews 23, 851-859.

Rozanski, K., Araguas-Araguas, L., Gonfiantini, R., 1992. Relation between long-term trends of oxygen-18 isotope composition of precipitation and climate. Science 258, 981-985.

Rozanski, K., Araguás-Araguás, L., Gonfiantini, R., 1993. Isotopic patterns in modern global precipitation. In: Swart, P.K., Lohman, K.C., McKenzie, J., Savin, S. (Eds.), Climate Change in Continental Isotopic Records, American Geophysical Union, Geophysical Monograph vol. 78, pp. 1-36 (Washington, DC).

Rupper, S., Steig, E.J., Roe, G., 2004. The relationship between snow accumulation at Mt. Logan, Yukon, Canada, and climate variability in the North Pacific. Journal of Climate 17, 4724-4739.

Shemesh, A., Rosqvist, G., Rietti-Shati, M., Rubensdotter, L., Bigler, C., Yam, R., Karlén, W., 2001. Holocene climatic change in Swedish Lapland inferred from an oxygen-isotope record of lacustrine biogenic silica. The Holocene 11, 447-454.

Siegenthaler, U., Eicher, U., 1986. Stable oxygen and carbon isotope analyses. In: Berglund, B.E. (Ed.), Handbook of Holocene Paleoecology and Paleohydrology. J. Wiley, Chichester, pp. 407-422.

Spear, R.W., Cwynar, L.C., 1997. Late Quaternary vegetation history of White Pass, Northern British Columbia, Canada. Arctic and Alpine Research 29, 45-52.

Spooner, I.S., Barnes, S., Baltzer, K.B., Raeside, R., Osborn, G.D., Mazzucchi, D., 2003. The impact of air mass circulation dynamics on Late Holocene paleoclimate in northwestern North America. Quaternary International 108, 77-83.

Streten, N.A., 1974. Some features of the summer climate of interior Alaska. Arctic 27, 272-286.

Stuiver, M., Reimer, P.J., Bard, E., Beck, J.W., Burr, G.S., Hughen, K.A., Kromer, B., McCormac, F.G., v.d.Plicht, J., Spurk, M., 1998. Radiocarbon age calibration 24,000-0 cal BP. Radiocarbon 40, 1041-1083.

Szeicz, J.M., MacDonald, G.M., 1995. Dendroclimatic reconstruction of summer temperature in Northwestern Canada since A.D. 1638 based on age-dependent modeling. Quaternary Research 44, 257-266.

Szeicz, J.M., MacDonald, G.M., 1996. A 930-year ring-width chronology from moisture sensitive white spruce (Picea glauca Moench) in Northwestern Canada. The Holocene 6, 345-351.

Talbot, M.R., 1990. A review of the palaeohydrological interpretation of carbon and oxygen isotopic ratios in primary lacustrine carbonates. Chemical Geology, Isotope Geosciences Section 80, 261-279.

Thompson, R., 1986. Paleomagnetic dating. In: Berglund, B.E. (Ed.), Handbook of Holocene Paleoecology and Paleohydrology. J. Wiley, Chichester, pp. 313-328.

Trenbirth, K.E., Hurrell, J.W., 1994. Decadal atmosphere-ocean variations in the Pacific. Climate Dynamics 9, 303-319.

von Grafenstein, U., Erlenkeuser, H., Muller, J., Trimborn, P., Alefs, J., 1996. A 200 year mid-European air temperature record preserved in lake sediments: an extension of the $\delta^{18} \mathrm{Op}$-air temperature relation into the past. Geochimica et Cosmochimica Acta 60, 4025-4036.

Wahl, H.E., Fraser, D.B., Harvey, R.C., Maxwell, J.B., 1987. Climate of the Yukon, Climatological Studies Number 40. Environment Canada, Ottawa, pp. 323.

Wake, C.P., Yalcin, K., Gundestrup, N.S., 2002. The climate signal recorded in the oxygen-isotope, accumulation and major-ion time series 
from the Eclipse ice core, Yukon Territory, Canada. Annals of Glaciology 35, 416-422.

Wang, X-C., Geurts, M., 1991. Late Quaternary pollen records and vegetation history of the southwest Yukon Territory: a review. Géographie Physique et Quaternaire 45, 175-193.

Wiles, G.C., D’Arrigo, R.D., Jacoby, G.C., 1998. Gulf of Alaska atmosphere-ocean variability over recent centuries inferred from coastal tree-ring records. Climatic Change 38, 289-306.

Wiles, G.C., Barclay, D.J., Calkin, P.E., 1999. Tree-ring-dated 'Little Ice Age' histories of maritime glaciers from western Prince William Sound, Alaska. The Holocene 9, 163-173.
Wiles, G.C., D’Arrigo, R.D., Villalba, R., Calkin, P.E., Barclay, D.J., 2004. Century-scale solar variability and Alaskan temperature change over the past millennium. Geophysical Research Letters 31, LI5203.

Wolfe, B.B., Edwards, T.W.D., Jiang, H., MacDonald, G.M., Gervais, B.R., Snyder, J.A., 2003. Effect of varying oceanicity on early- to midHolocene palaeohydrology, Kola Peninsula, Russia: isotopic evidence from treeline lakes. The Holocene 13, 153-160.

Yu, Z., McAndrews, J.H., Eicher, U., 1997. Middle Holocene dry climate caused by change in atmospheric circulation patterns: evidence from lake levels and stable isotopes. Geology 25, 251-254. 